Historic, archived document

Do not assume content reflects current scientific knowledge, policies, or practices. 

7.<smiles>C1CCCCC1</smiles> 


$$
\%
$$



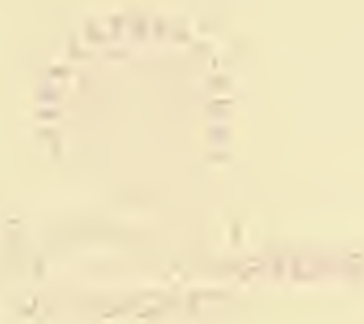







\author{
O R O N O
}

BULLETIN 276

MARCH, 1919

\title{
THE MEADOW PLANT BUG.
}

CONTENTS

PAGE

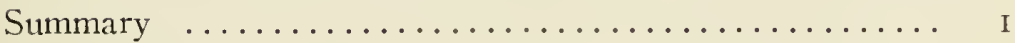

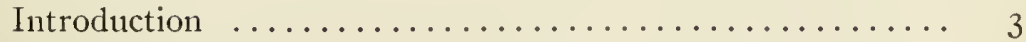

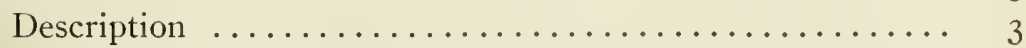

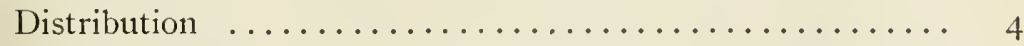

Believed to be an Introduced Species............ 4

Distribution in Maine........................ 5

Economic Importance ..................... 6

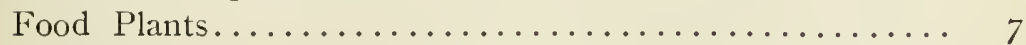

Dimorphism ............................ 8

Life History .......................... 8

Natural Enemies ........................ I I

Measures for Control.................... I4 


\section{MAINE}

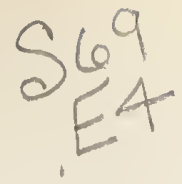

AGRICULTURAL EXPERIMENT STATION ORONO, MAINE

THE STATION COUNCIL

PRESIDENT ROBERT J. ALEY, DIRECTOR CHARLES D. WOODS, THOMAS V. DOHERTY, Houlton, FRANK E. GUERNSEY, Dover, CHARLES S. BICKFORD, Belfast, JOHN A. ROBERTS, EUGENE H. LIBBY, Auburn, WILSON W. CONANT, Buckfield, FRANK S. ADAMS, Bowdoinham, President Secretary LEONARD C HOLSTON, Cornish, Maine Livestock Breedrs' Ass' WILLIAM G. HUNTON, Portland, Maine Seed Improvement Ass'n.

And the Heads and Associates of Station Departments, and the Dean of the College of Agriculture

\section{THE STATION STAFF}

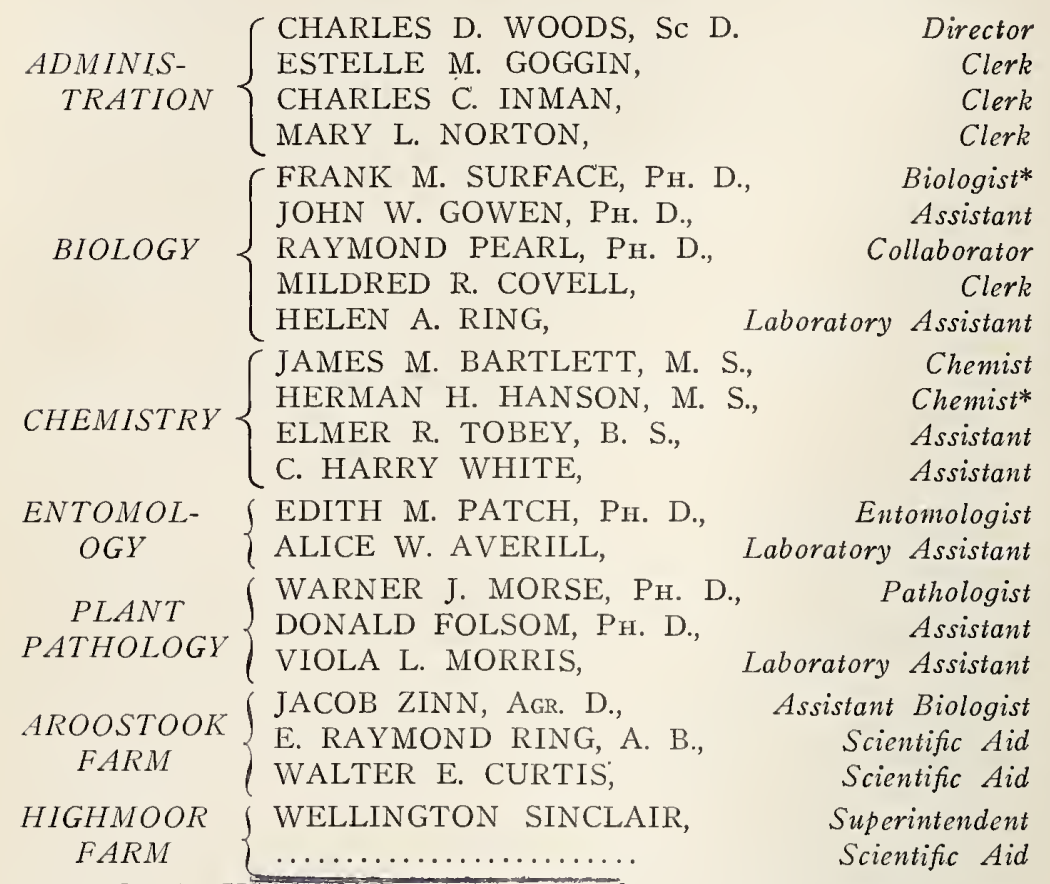
ROYDON L. HAMTBRARPOF CONGRESS epd Analyst and Photographer

* Absent on lqave fitupitg perio1937 wan. 
BULLETIN 276

\title{
THE MEADOW PLANT BUG *
}

\author{
Herbert Osborn
}

\begin{abstract}
Research Professor of Zoology and Entomology, Ohio State University, and Consulting Entomologist, Maine Agricultural Experiment Station
\end{abstract}

\section{SUMMARY}

1. Miris dolabratus has been a conspicuous insect in timothy meadows in portions of the eastern United States during the past 40 years and now has a distribution as far west as Illinois and Minnesota and south in the Mississippi valley into Kentucky.

2. It is believed to be an introduced species coming from Europe with timothy hay or other large stemmed grass shipped for forage or packing sometime between 1800 and 1825 .

3. It feeds upon cultivated grasses especially timothy, orchard grass and meadow fescue and when abundant must seriously affect the value of the crop.

4. It is a dimorphic species, there being two forms of females, a long-winged and a short-winged form, the latter being far more plentiful, something like 90 per cent of all females.

5. The species hibernates in the egg form, hatching occurs about May 25th to June 10th in Maine, and the nymphs pass through 5 instars of about 6 or 7 days each, adults occurring from early July, mating and laying eggs from July 10th to August 1st for the short-winged forms necessarily in the fields where the females have developed.

*Papers from the Maine Agricultural Experiment Station: Entomology No. 101. This bulletin is based on a more detailed paper by the same author, published under the title "The Meadow Plant Bug, Miris dolabratus;" Journal of Agricultural Research, Vol. XV, No. 3. 
6. The eggs are laid in stems of grass or clover in fields where females have grown, being thrust through the wall of the stem and held by an expanded cap which is firmly held by the walls of the stem, the egg being protected in the hollow of the stem and in this position remain for at least 8 or 9 monthsi before hatching.

7. Measures for control so far evident and based on habits determined will consist especially of rotation, with probably some advantage from burning, early cutting, pasturing heavily in fall, and possibly by mechanical devices for capturing the nymphs or adults.

8. The spread of the insect should be prevented by care in the disposition of timothy hay moved to a distance. No hay from an infested district should be allowed to be scattered in or near meadows in localities where the insect is not already present.

9. Natural enemies consist so far as at present known of spiders, the predaceous damsel bugs Reduviolus sps. a Tachinid fly Phorantha occidentis and an undetermined species and a species of fungus Entomophthora sp. 


\section{INTRODUCTION}

This species presents a number of interesting problems, biologic as well as economic, and considering its great abundance over a large area of the eastern United States and Canada during the past forty years it seems strange that it has not received more careful investigation.

My own attention was attracted by its appearance in immense numbers in northern Ohio at about the time of my removal to that state in 1898 . It was entirely unknown to me from previous field collecting and specimens I had seen were collected in western New York by Mr. E. P. Van Duzee about the year I 888.

My attention was again forcibly attracted to the species by the great abundance in Maine in I9I4 when they were encountered in my studies of the meadow leafhoppers. A reference to the literature indicated almost total neglect of the species in this country and almost nothing concerning its economic importance was found. It seemed therefore well worth a special study and I was gratified to be able to arrange with the Maine Agricultural Experiment Station to undertake a summer's study of the species at Orono.

As an old-world species the insect has evidently been familiar since it was described by Linne (I758) and has had frequent mention by later writers who have treated it simply from the systematic standpoint. Wolff ( 1802 ) indeed gives a recognizable figure of the nymph in one of the later instars also a rough sketch of the egg but so far as noted no detailed study of life-history, habits or economic status has been made even in the regions where it has been longest known.

\section{Description}

No very satisfactory description of the species is available in the accessible text books or manuals. The adults are about two-fifths of an inch long, (9 mm.) rather slender, with long black antennae which are thickest at the base, the head rounded, set fairly close to the thorax which widens behind and the wings lie nearly flat on the back are narrow and have nearly parallel sides, extend to or slightly beyond the tip of the abdomen in the males and long-winged females and to the fifth abdominal 
segment in the short-winged females. The color is yellow or yellowish gray with dark markings which form two rather indefinite stripes on the pronotum and elytra. The antennae and legs are black with yellowish bases or yellow with black hairs and spots.

The nymphs are yellow marked with black, the general color being quite dark in the early instars and becoming lighter with the successive moults.

\section{Distribution}

The range of the species is evidently throughout a large part of Northern Europe and North America but in this country it has been especially noticeable in Eastern Canada, New England, New York and West into Ohio. Reports from a number of states establish its occurrence in large numbers and the records given support the view that it is an old world species which has gained introduction within the past century.

\section{Believed to be an Introduced Species}

With the evidence available there seems to be good reason to believe the species to have been introduced from Europe at some time not later than the early part of the last century, probably not earlier at best than about 1800 and, if we may give weight to the first records by Uhler and Provancher we may suppose an introduction in New England or at Quebec or some of the maritime provinces of Canada, perhaps equally probable for Nova Scotia, New Brunswick or Quebec. From any of these localities the dispersal might easily reach the other localities concerned in the course of a few decades though without artificial assistance its progress must be slow.

Evidence in favor of the species being an introduced one may be summed up briefly as follows:

First: It has been a common insect in Europe for an indefinite period, covering a large area and doubtless associated with the cultivated grasses to which it seems so closely restricted here.

Second: The species was not known in America until about I830 when it was collected by Harris as noted by Uhler and later recorded by Provancher altho a number of 
careful students such as Say, Uhler and Walsh had given no little attention to the insects of the group to which it belongs and would almost certainly have encountered it in their work, if it had been present in any abundance, in different parts of the country where it now occurs.

Third: It has shown a gradual westward and southward dispersal as indicated by the available records of occurrence. This shows occurrence in New England in I832, Maryland I868, Quebec I872, New York I887, Ohio I 888 (?), Ill. I906, Kentucky I908.

Fourth: It is adapted to certain cultivated grasses which were introduced from Europe and its close restriction to these and apparent inability to adapt itself to native grasses even of as large forms as the cultivated ones is very significant.

Fifth: In the plan of hibernation of eggs in stems, there is evidently furnished abundant opportunity for the transportation of eggs to distant points in hay shipped for forage or packing.

\section{Distribution in Maine}

The species has certainly been present and abundant in Maine for many years but except for the notes by Prof. $\mathrm{H}$. T. Fernald there does not appear to have been any record that assists in determining the time of its appearance or the extent of distribution. The Experiment Station collection contains several specimens those bearing dates for Orono being July I 4 th and I8th I905 and July IIth I907, all being adults and Dr. Patch published a record of its abundance in I908. As mentioned elsewhere the writer noted it as abundant ir I9I4 at Orono. Prof. C. L. Metcalf took specimens and noticed the species as abundant in late instars and adult males at Fort Kent July 5 th and 6th, at Presque Isle mostly adults on July 8th and at Houlton as adults with few nymphs of late instars on July 9th for the summer of I9I6. The writer found them abundant at Phillips and other points where timothy meadows were examined between Farmington and Dallas on July I8th I9r6 and also very plentiful in some old meadow land in the vicinity of Saddleback Lake on July Igth and 2oth. None oc- 
curred on Saddleback Mt. at any point above the level of the meadow land or the growth of the timothy and other grasses commonly occupied by the species.

It is evidently safe to assign its distribution in the state to all parts where suitable grasses occur and it may confidently be expected to occur in all old meadow land where timothy forms a part of the combination during the months of June, July and August and search in the stems will be pretty sure to disclose them as eggs during other months of the year.

\section{ECONOMIC ImPORTANCE}

While, from the great numbers appearing in meadows and the evident attack on the plants, it must be inferred that there is serious injury to the crop there appears to be little to establish the amount of loss or to separate it from that due to other species. In fact but few of the Capsidae have been given much attention from the economic standpoint. The familiar and cosmopolitan tarnished plant bug, Lygus pratensis, has been known for years as a pest to many plants. In I892 Dr. L. O. Howard called attention to Oncognathus binotatus as "A New Enemy to Timothy Grass." Dr. M. V. Slingerland has treated the common four-lined plant-bug (Poecilocapsus lineatus) as a pest of currants, Professor Popenoe the little Haltica bractatus or uhleri as a garden pest of beans and the common Calocoris rapidus has been known for many years to affect the clover crop.

Some idea of the effects produced by the meadow plant bug may be secured by noting the enormous numbers that are hanging to the plants and especially to the heads during the time the timothy is in bloom. Often a number may be seen clinging to a single head, from three to five being not unusual. The fact that they suck the bloom doubtless means a heavy loss in seed or in weight and nutritive value of hay, although there is little external evidence of injury.

Evidence of injury based on the amount of hay per acre where these insects are plenty as compared with fields where they are absent suffers from the fact that so many different insects are present and it is almost impossible to determine the proportion to be charged to each. Judged merely by the num- 
bers present and also by the size and feeding capacity of these insects they may easily be counted among the most destructive to the crop though they do not kill the plant by attacks at or near the root.
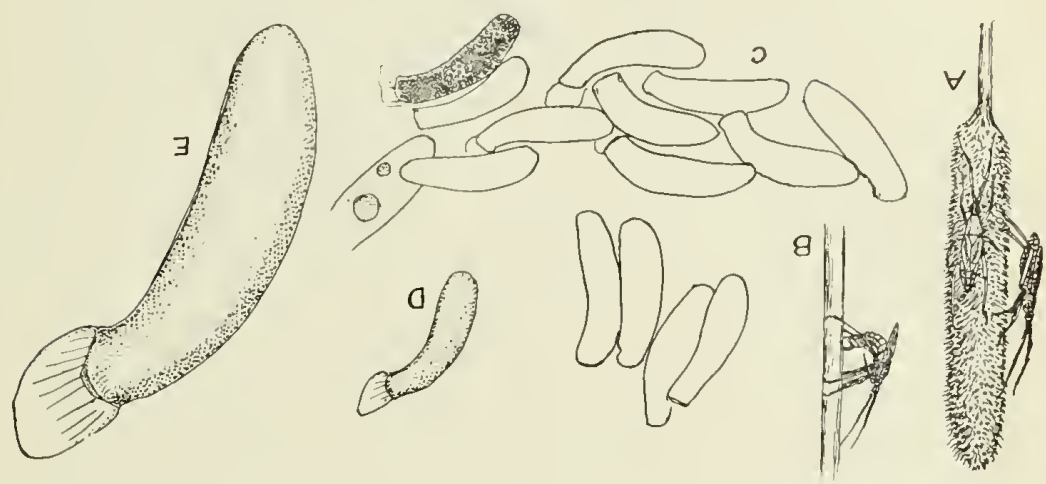

Fig. 1. Miris dolabratus: A, adult on timothy head in resting or feeding position; $\mathrm{B}$, female ovipositing; C, eggs from oviduct, nearly or quite mature; $\mathrm{D}$, mature egg ready for deposition; $\mathrm{E}$, mature egg greatly enlarged showing membranous operculum. From drawings by the author. (Jour. Agr. Research).

\section{Food Plants}

Timothy has been most commonly mentioned as the food plant of the species and this is quite evidently the grass with which it is most commonly associated as even where it may be found on other grasses it is usually where timothy forms a large part of the combination of species growing together.

I have found it commonly attached on timothy heads, very evidently feeding, and individuals have been carried along for several instars with no other food, so this is clearly a normal food supply (fig. I). I have also found it commonly on orchard grass, meadow fescue and witch grass and the nymphs seem to thrive on these plants about as well as on the timothy. It has not been observed commonly on blue grass or other small grasses or grasses with small seed heads except as these are mixed with the coarser forms and while it occurs where clover is mixed with timothy and lays eggs in clover stems it has not been observed ever to feed either on stems, leaves or 
heads of clover. I believe it is quite strictly a grass feeding species and primarily adapted to timothy.

Before the grasses head out they occur on the stems and leaves but the larger part of the growth occurs after timothy begins to head and the heads seem to be the favorite point of attack. The insects cluster on the heads sometimes in numbers to a single head and thrust their beaks down into the flowerets evidently drawing their food from the tender parts of the blossom or from the forming seed. I have seen a female thrust the beak down in the flower of a witch grass pierce the glumes or insert the beak between and down into the anthers penetrating the anthers and causing them to burst and probably sucking juices from the ovules. Mrs. Slosson's (I894) record for Mt. Washington above 5500 feet is for adults and Mr. C. W. Johnson informs me that many insects capable of flight are carried up by air currents and found at altitudes much above their food plants.

\section{DiMORPHISM}

The species occurs in two distinct forms of females a long-winged and a short-winged form but only one form of male, the long-winged, has been observed. The short-winged form of female is by far the most abundant and as this form is entirely unable to fly and therefore is very definitely restricted in its migration it is of special interest to note that it must be the form which produces practically all of the eggs.

\section{Life History}

The eggs hatch in May or early June the time being determined in part by latitude and season. The exact date of hatching at Orono was not observed as nymphs were already abundant at the time of my arrival June I2th and as the season of I9I6 was exceptionally late it is probable that the average date of hatching would be the last week in May. Young nymphs continued to appear until about June 25th and none after July Ist while the first adults appeared June I6th and were abundant by June 26 th. 
Evidently the adults feed for some time before mating as the first matings observed were July 8th and roth. The eggs however develop rapidly when the insects reach the adult stage as fully developed eggs in large numbers, 50 to 60 to the individual, were dissected from the females, the first one dissected, June 30 , containing 30 fully formed and others immature. Another, dissected on July 8, contained 69 developed and a few immature eggs.

These dissected eggs were of special interest as they might furnish the clue to later determination of place and method of oviposition and the peculiar strongly curved neck and large membranous expansion over the head naturally suggested some rather unusual mode of placement.
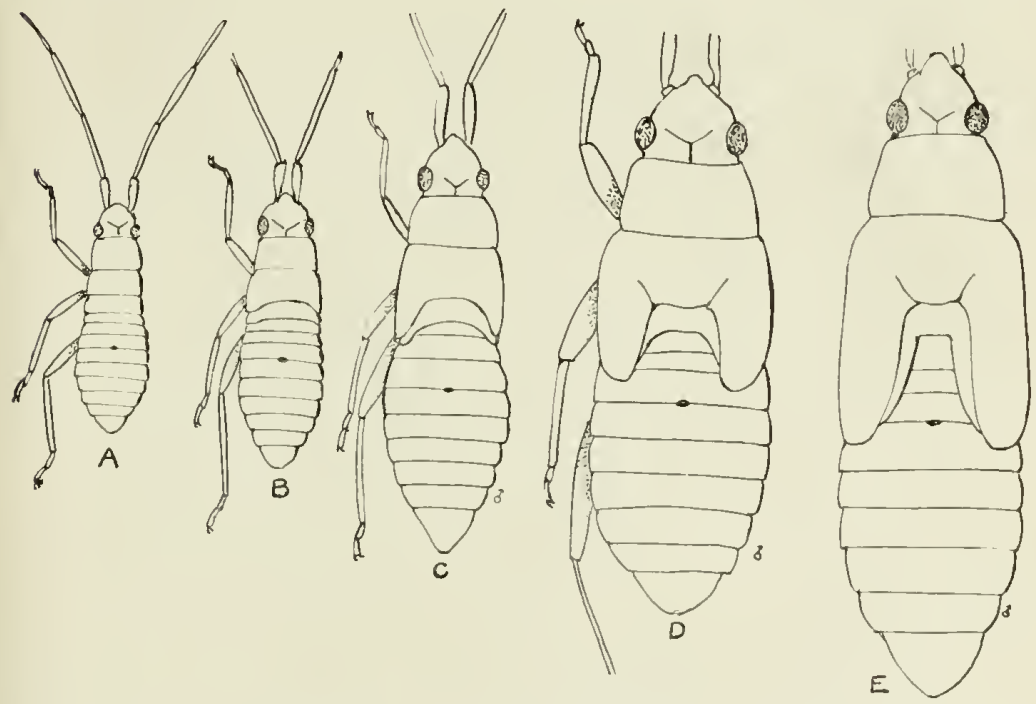

Fig. 2. Miris dolabratus: Nymphs showing relative size of body and development of wing pads. A, first instar; B, second instar; C, third instar; D, fourth instar; $\mathrm{E}$, fifth instar. Note also position of dorsal gland orifice between segments 3 and 4 . From drawings by the author. (Jour. Agr. Research).

The nymphs cling closely to the plants and while they pass readily up and down the stems and doubtless shift from one plant to another there is no extended migration, probably no movement providing for any dispersal. When molting they 
cling to the plant and, as with other insects generally, the skin splits along the middle line of the back and the body and legs are gradually withdrawn and the increase in size and resumption of color takes place in a short time.

Five distinct stages of the nymphs are recognized and this seems to be the genenal rule for the Hemiptera, being the number noted in a large number of the species which have been reared through the nymphal stages (fig. 2).

No single individual has been carried from the first instar through to the adult stage but numbers have been carried from two to four of the instars in confinement and under observation so that it is possible to give a connected series of stages from the smallest found to the adult form. The time occupied in the different stages has run from 5 to 8 days, averaging 6 to 7 days, and the total period of development from hatching to adult stage must be about 30 to 35 days.

The principal changes are in the increase in size and in the growth of the wing pads which are entirely wanting in the first, appear as faint enlargements of the meso-thorax in the second instar, are fairly distinct on both meso- and meta-thorax in the third, extend to the second abdominal segment in the fourth and on to the middle of the fourth segment in the fifth for the female and to the base of the fifth segment for the male. There is considerable irregularity in development as instars I-4 and probably 5 with adults were taken June 23 .
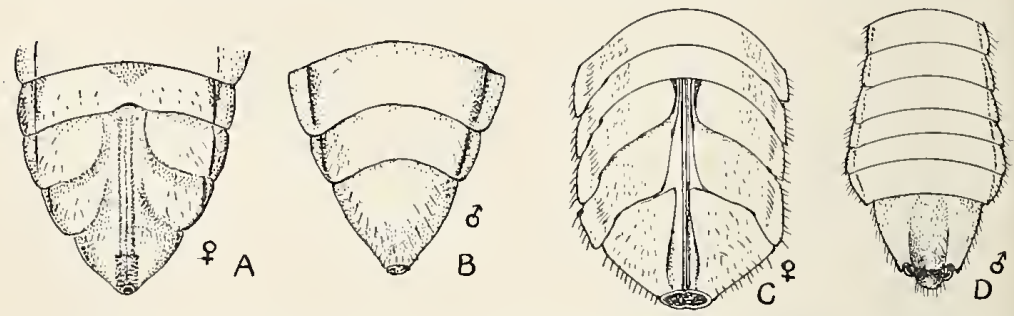

Fig. 3. Miris dolabratus: genital segments: A, female; $\mathrm{B}$, male of fifth instar nymph; C, female; D, male of adult. From drawings by the author. (Jour. Agr. Research).

In the fourth and fifth instars the sexes are easily distinguished, males being slightly narrower, the abdomen with more 
parallel sides, and the genitalia being seen in outline through the semitransparent walls (fig. $3 a \& b$ ).

With the final molt the wings expand rapidly and the distinction between males and females and the dimorphic forms of fenales become clearly marked.

The adults remain quite constantly on the grass heads and evidently feed for a number of days before mating or egg laying begins.

On the grass heads they are more commonly found with the heads directed upward and they show some tendency to mount to the highest point but they often stand head downward and pass up and down the heads and stem freely. The position with the head upward appears to give them an excellent position for probing into the florets with their beaks. It was noted that in egg laying the females selected small stems of grass $\mathrm{I} \mathrm{mm}$. to $\mathrm{I} / 2 \mathrm{~mm}$. in diameter while in clover stems as much as $2 \frac{1}{2} \mathrm{~mm}$. diameter were used. Probably the rough or softer stem of clover serves as a good foothold though the tarsi are too small to clasp around it.

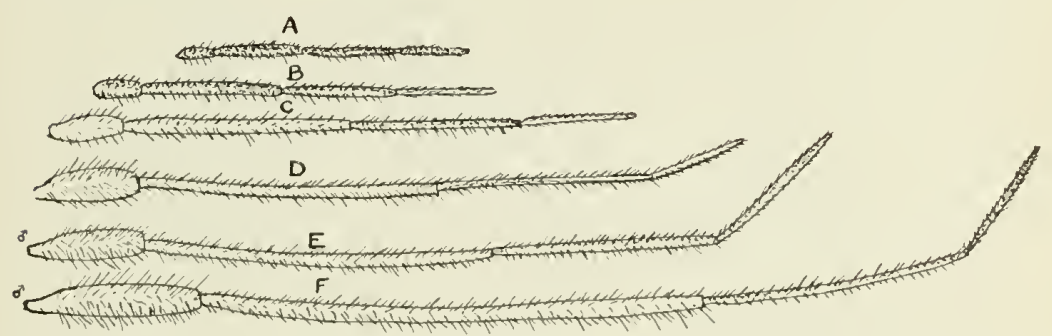

Fig. 4. Miris dolabratus: A-E, antennae of nymphs; F, antenna of adult drawn to same scale and showing relative lengths of segments. From drawings by the author. (Jour. Agr. Research).

\section{Natural Enemies}

Among the natural enemies or checks of the species may be counted the gray damsel bug, Reduviolus ferus, (fig. 5) which is a very common and widely distributed species throughout the northern part, at least, of North America and in fact the holarctic region. Webster and Mally (I897) say Corsicus ferus was observed to attack Leptoterna dolobrata Linn. which was feeding quite abundantly on timothy heads about East Cleveland, June 28, I896. 
This species has been found in Maine associated with Miris dolabratus as well as with the leafhoppers and it is probable that it may feed on either with equal avidity. While not seen feeding on the mature Miris it is pretty certain that it will feed upon the larvae and its fondness for leafhoppers in both the nymph and adult stages has been proven by repeated observation. Direct observation on the insects attacked is difficult as it is almost impossible to follow them in their movements in the field and even when offered a variety of food in confinement it is difficult to determine as to their selection in the species offered as they very seldom make their attacks on the insects while under observation and it is left to infer from the numbers killed how ready they are to prey upon different kinds of insects. We have had them live and thrive in confinement and progress to the adult stage on a diet of Miris and also on a food supply of leafhoppers and it is probable that they will eat a variety of small insects the particular kinds being determined rather by the available supply than by any definite choice on the part of the bug. They are able to survive considerable periods without food, and their development is doubtless affected by abundance or scarcity.

Reference has been made to the record of Leonard of rearing Phorantha occidentis from Miris dolabratus in New York. A larva apparently a Tachinid was secured issuing from a nymph of Miris at Orono June I7, 1916, but it failed to mature. On July I8, I9I6 a nymph which issued from Miris buried itself promptly in earth and from this an adult emerged July 29th. This larva issued from the anterior part of the abdomen under the wings while the host was still alive. The species has not been determined but is evidently closely related to the species bred by Leonard.

Spiders are undoubtedly quite efficient enemies of the plant bugs but they dispose of their prey so completely that little is left as evidence of their work. Mr. Fletcher found a Miris encircled by a spider's web in which it had evidently been captured and enmeshed. In some unpublished records made by Mr. Sherman Bilsing in Ohio a number of different species of spiders are credited with feeding on this species along with many other capsids. 


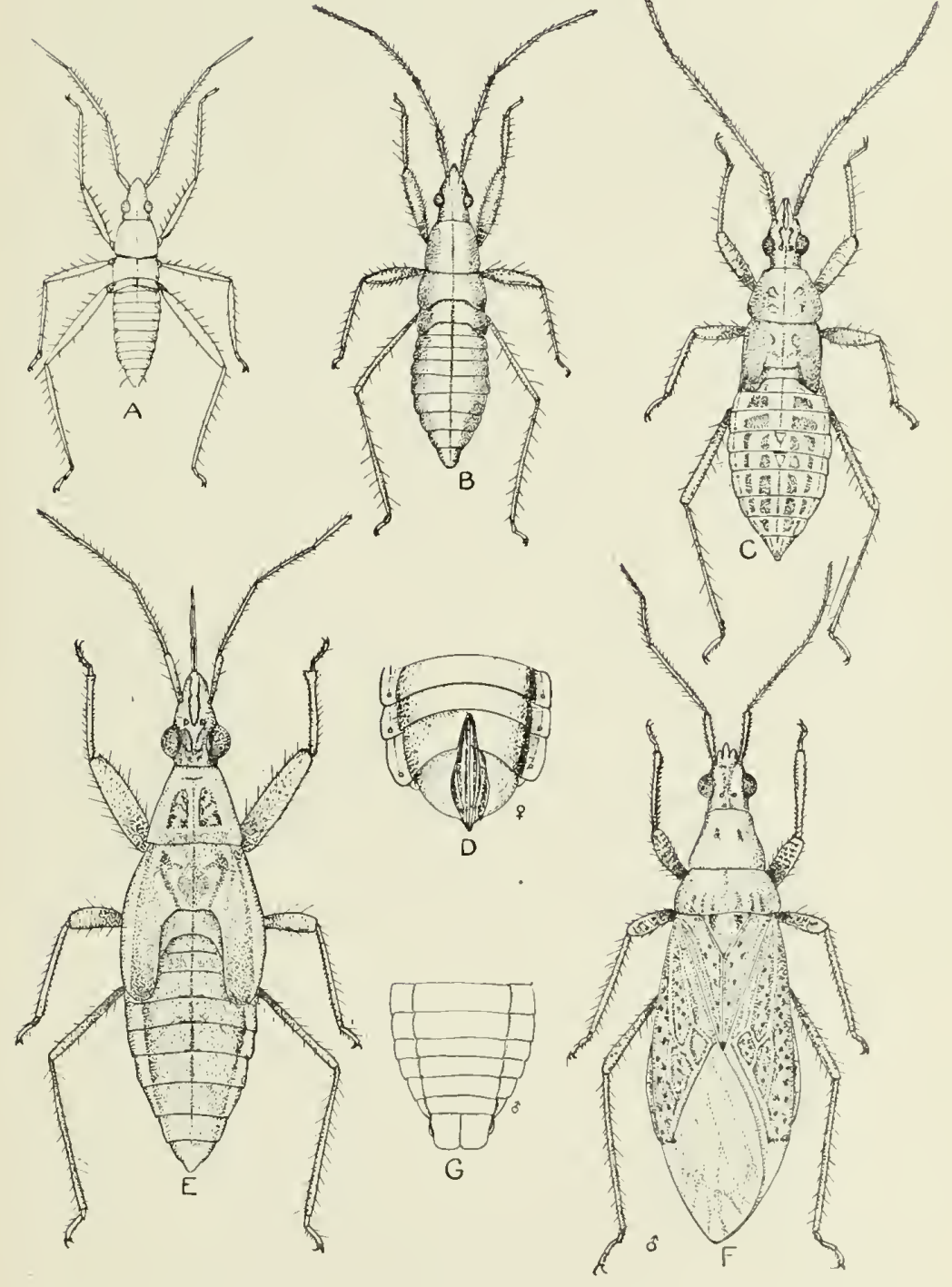

Fig. 5. Reduviolus ferus: A, first instar; B, second instar; C, third instar; D, genital segments of female; $E$, fifth instar; F, adult male; G, genitalia of male. From drawings by the author. (Jour. Agr. Research). 
The extent to which birds, toads and other animals may serve to reduce their numbers is open to study.

Certain fungi which attack insects may also be considered as possible checks on this species. While no extended effort has been possible we have found one form at least which is probably nearly related if not identical with a form occurring on aphids. (Entomophthora aphidis.)

\section{Measures for Control}

While the main efforts during this summer's studies have been directed toward solving a number of puzzling questions as to the development and habits of the species and while some definite experiments are needed with certain measures that may be suggested on the strength of the facts learned there is certainly a very definite basis established for certain kinds of treatment that should do much to reduce the numbers of the insect.

The most fundamental point determined with reference to the insect in connection with control is doubtless the fact that the eggs are deposited in the stems of plants in the fields where the insect has been present. This, in connection with the fact that the great majority, probably ninety per cent of the females, are wingless, means that we know that practically all the eggs deposited in mid-summer are in the old timothy meadows and that any measure which will destroy them in this location will have immediate effect in preventing further loss from this source.

It is very evident that plowing under and planting of the field to a different crop will absolutely prevent further injury from the stock of insects established in any old meadow and therefore rotation where this is practicable may be counted a certain remedy for the field concerned. However, for the protection of adjacent fields or in order to exterminate the insect as completely as possible the borders of the fields and the fence rows usually supporting a considerable growth of grass should be remembered and, for the disposal of this insect, should be plowed as closely to the border as possible or burned over when the grass is dry so as to destroy the eggs as completely as possible. 
Where rotation is impracticable or undesirable it will be more difficult to secure complete eradication and careful tests of treatment based on the habits of the insect are necessary to determine the most successful methods.

It is clear that burning over of meadows if sufficiently dry in autumn or early spring so as to destroy the eggs would be very effective but there are of course many objections to this treatment so that it can not be urged as sufficient. In some seasons probably there would be no time when the grass would burn sufficiently close to the ground to destroy any large part of the eggs and there is the danger if burned too deeply that the stand of grass will be injured. This method especially for the conditions prevailing in Maine does not seem to promise much. Where burning is practiced, it should assist. It would be worth while to compare results in fields so treated.

Early or late cutting of the crop may have some effect on the number of eggs laid in a field, an early cutting before the insects are mature for example depriving them of their usual form of food, the heads of grass, may reduce egg deposition but whether to such an extent as to warrant any special change in the usual practice as to time of cutting can only be determined by further study.

The application of any form of insecticide or of special kinds of fertilizers does not seem to offer any very practical relief and the use of hopper-dozers or mechanical devices for their capture have not been tested; nor do they have much promise.

Finally there is the important consideration of the spread of the insect into adjacent fields or farms or to more distant points and for this the facts secured furnish a very sure foundation for effective control. Knowing that practically the only opportunity for such wider distribution is by carriage of hay, attention to the disposal of any such material introduced where the insect is not present, in some way to avoid scattering of eggs where they can hatch where suitable food plants will be available for their subsistence, will serve to exclude them. 


\section{ACKNOWLEDGMENT}

I am indebted to a number of persons for assistance in the preparation of this report, especially to Dr. Edith M. Patch for facilities to carry forward the study and to Mr. R. K. Fletcher for careful attention to field observations and to the entomologists of various states who have kindly taken the trouble to send records for their territory.

\section{Description of Plates}

Fig. 6. Miris dolabratus: A.- $a$, Eggs in grass stem, all hanging in one direction; $b$, eggs in grass stem placed in opposite directions; $c$, same as upper part of $b$, more enlarged; $d$ and $e$, eggs in clover stems. Photographed by Mr. Hammond. (Jour. Agr. Research).

Fig. 7. Miris dolabratus: B. $-b$, Eggs at left; $I$, first instar; 2 , second instar; 3, third instar; $3+$, third instar more mature; 4 , fourth instar; 5, fifth instar; 6, adult male above, female below. Photographed by Mr. C. J. Drake. (Jour. Agr. Research). 

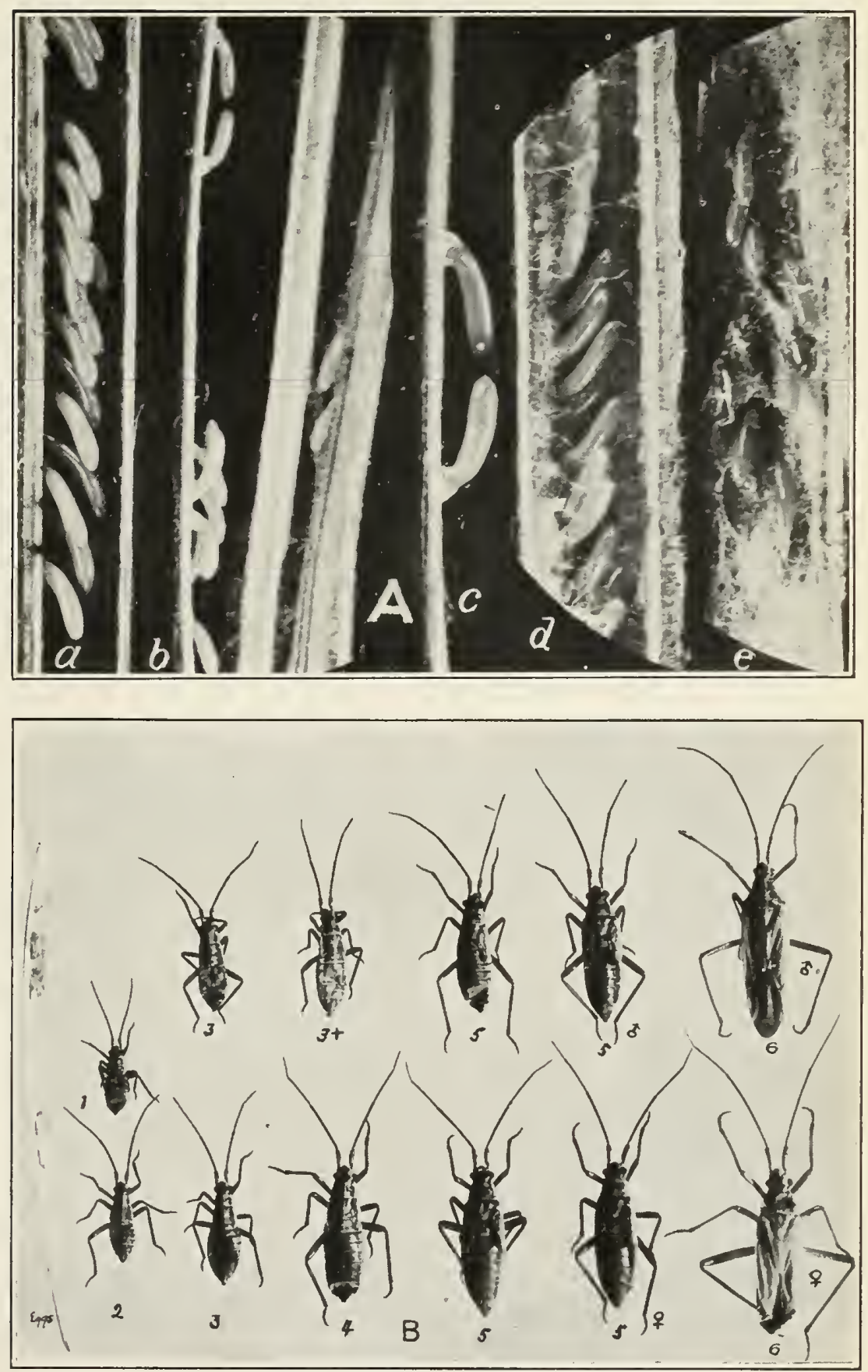

Miris dolabratus. Figs. 6 and 7. 


